\title{
Corrigendum: Sclerochronological Study of a Glycymeris vanhengstumi Population From the Madeira Islands
}

\author{
Alexandra Németh ${ }^{1,2 *}$ and Zoltán Kern ${ }^{1,2 *}$ \\ ${ }^{1}$ Isotope Climatology and Environmental Research Centre (ICER), MTA ATOMKI, Debrecen, Hungary, ${ }^{2}$ Institute for \\ Geological and Geochemical Research, MTA Research Centre for Astronomy and Earth Sciences, Budapest, Hungary
}

Keywords: sclerochronology, Glycymeris, subtropical North Atlantic, sea surface temperature, ocean mixing

\section{A Corrigendum on}

Sclerochronological Study of a Glycymeris vanhengstumi Population From the Madeira Islands by Németh, A., and Kern, Z. (2018). Front. Earth Sci. 6:76. doi: 10.3389/feart.2018.00076

\section{OPEN ACCESS}

Approved by:

Frontiers in Earth Science Editorial Office,

Frontiers Media SA, Switzerland

*Correspondence:

Alexandra Németh

nemethalexandra89@gmail.com

Zoltán Kern

kern.zoltan@csfk.mta.hu

Specialty section:

This article was submitted to Quaternary Science, Geomorphology and Paleoenvironment, a section of the journal Frontiers in Earth Science

Received: 11 February 2019

Accepted: 13 February 2019

Published: 13 March 2019

Citation:

Németh A and Kern Z (2019)

Corrigendum: Sclerochronological Study of a Glycymeris vanhengstumi Population From the Madeira Islands.

Front. Earth Sci. 7:34. doi: 10.3389/feart.2019.00034
In the original article, there was an error. The scientific name of the studied bivalve species has been misspelled as "Glycymeris vangentsumi." The correct spelling should be "Glycymeris vanhengstumi" (Goud and Gulden, 2009). The spelling mistake appeared throughout the entire manuscript and, most regretfully, in the title. The same spelling mistake occurred in the legends for Figures 2, 3, 4, 6 , and 7.

In addition, we thanked the IIMAR-Madeira organization instead of Dr. Kai George. A correction has been made to the Acknowledgement. It should read:

"We are grateful to the editor, Michael Hermoso and the three reviewers for their helpful and constructive comments. The authors would like to thank Dr. Kai George, from the German Center of Marine Biodiversity, who organized and partially financed the POS466 cruise of the research vessel Poseidon. The help of the captain and the crew of Poseidon is also greatly appreciated. Thanks to Jeroen Goud for his help with the identification of the shells and the INCREMENTS Group (Johannes Gutenberg University, Mainz, Germany) where we were given the opportunity to prepare the samples. This is contribution No.58. of 2 ka Palæoclimatology Research Group."

The authors apologize for these errors and state that these do not change the scientific conclusions of the article in any way.

\section{REFERENCES}

Goud, J., and Gulden, G. (2009). Description of a new species of Glycymeris (Bivalvia: Arcoidea) from Madeira, Selvagens and Canary Islands. Zoologische Mededelingen Leiden 83, 1059-1066.

Copyright (C) 2019 Németh and Kern. This is an open-access article distributed under the terms of the Creative Commons Attribution License (CC BY). The use, distribution or reproduction in other forums is permitted, provided the original author(s) and the copyright owner(s) are credited and that the original publication in this journal is cited, in accordance with accepted academic practice. No use, distribution or reproduction is permitted which does not comply with these terms. 